Article

\title{
How Do Configuration Shifts in Fragmented Energy Governance Affect Policy Output? A Case Study of Changing Biogas Regimes in Indonesia
}

\author{
Ibnu Budiman *(1) and Mattijs Smits \\ Environmental Policy Group, Wageningen University and Research, 6708 PB Wageningen, The Netherlands; \\ mattijs.smits@wur.nl \\ * Correspondence: budimanibnu26@gmail.com
}

Received: 12 December 2019; Accepted: 10 February 2020; Published: 13 February 2020

check for updates

\begin{abstract}
Biogas technology to support rural livelihoods and low-carbon development has been developed in different projects and programs in the Global South over the last few decades. However, the existence of multiple projects, actors and designs involved may lead to so-called fragmentation in governance. This research addresses the fragmented governance amongst the biogas programmes in Indonesia to study their impact on the implementation; the numbers of biodigesters disseminated and knowledge transferred. Drawing on concepts of fragmentation, regime effectiveness, and policy output, the research uses data from interviews with relevant actors, supplemented with documents review. Findings show that the governance architecture of biogas regime in Indonesia consists of different types of biogas programmes championed by different types of actors pursuing different objectives. There had been patterns and periodical shifts of configuration within the Indonesian biogas regime, i.e., from administrative fragmentation (2007-2009), to conflictive fragmentation (2010-2012), to cooperative fragmentation (2013-2016), and reduced fragmentation (2017). Shifting from administrative to cooperative fragmentation resonates with the increase of the number of biodigesters dissemination more than fourfold in ten years, from 800 in 2007, to 37,999 in 2016. The distribution of power within the governance architecture among government bodies, NGOs, and the private sector influenced the speed of implementation and innovation of the biogas programs. This suggests that a higher degree of distribution of power and cooperation within a governance architecture contribute to increasing policy output of the regime complex of renewable energy.
\end{abstract}

Keywords: biogas; fragmentation; governance; Indonesia; regime complex; policy output

\section{Introduction}

Rapid economic growth in middle-income countries in the Global South has led to heavy dependence on fossil fuel for energy generation and rapidly rising carbon emissions [1,2]. These trends go against global climate agreements and national policies and programmes pushing for energy transitions towards more sustainable energy production and consumption. In terms of energy for cooking, the common dominant sources are liquefied petroleum gas (LPG) and firewood. In Indonesia, for example, about 40 percent of households still use firewood for cooking [3]. This practice contributes to forest degradation, climate change, and health issues [4].

In the context of energy transitions related to cooking, biogas is considered as a clean source that can be introduced, especially in the household level. The use of biogas as an energy source in the Global South is not new [5]. Since 1929, China has been the world leader in biogas production. In 2015, the country had a total production of 19 Giga cubic meters biogas with 50 million users [6,7]. Furthermore, there are roughly 4 million biogas digesters operating in India, whilst the use of biogas 
is also increasing in Vietnam, Brazil, and Tanzania [8,9]. However, the number is still relatively low, and uptake of biogas systems has generally been slow and sporadic. In Rwanda, Tanzania, China, India, and Nepal, the lack of government support through suitable policies and incentives is a barrier to dissemination of the biogas technology. Moreover, there is often a lack of collaboration between research institutions, governmental departments, and biogas users, to improve the technology's dissemination and appropriate, long-term use [10].

In Indonesia, biogas digesters (or biodigesters) have been promoted by different actors over the last few decades, using different (constructions) designs, financial approach, and promotion strategies. This has led to a so-called 'fragmented' governance landscape. Fragmentation of governance is the situation where the landscape of different actors and programmes is not fully interconnected and integrated, and there may be conflicting goals and approaches, due to a lack of interlinkages between institutions [11-14].

To date, most research on fragmentation has focused on issues related to global governance [11, $12,15-17]$, with only a few studies discussing the impact of fragmentation on policy output $[18,19]$. This study addresses the impact of an inherently fragmented regime, around renewable energy, on the national-level- on its policy output. Such regimes are particularly complex for large lower-middle income countries like Indonesia [20]. Moreover, while some studies have mentioned the urgency to assess (self-) organization of a fragmented governance system [11,18,21-23], a key methodological challenge is to work back from the observed outputs or outcomes of a fragmented system to make plausible claims about (causal) mechanisms $[19,24]$. This study makes a contribution to resolving this challenge. The key scientific problem addressed in this article is, thus, on how to link the fragmentated (renewable energy) governance landscape to policy outputs.

The fragmented biogas governance in Indonesia has so far had mixed results in terms of policy output; the numbers of biogas digesters implemented, and knowledge transferred between the different stakeholders involved. Until 2015, the total number of biogas digesters only accounted for 1.24 percent of households [3]. Dissemination barriers to biogas digester are found in several aspects; bureaucratic processes, the time-consuming process of feedstock, issues of social acceptance, different (energy) priorities, complex monitoring practices, and poor technological maintenance [14]. The key emphirical problem addressed in this article is, thus, on how to link the capability of the fragmentation in biogas governance in tackling dissemination barriers and affecting policy output in terms of levels of implementation of biogas digesters and knowledge transfer.

To contribute to abovementioned empirical and theoretical lacunas, this research explores the landscape of biogas governance architecture, its fragmentation, and the impact to policy output, in Indonesian context during the period of 2007 to 2017. Conceptually, this study contributes to an understanding of whether and how fragmentation is actually beneficial or harmful in terms of policy output, such as dissemination number and knowledge transfer. As such, this research develops critical knowledge of the forms and consequences of different types or configurations of governance fragmentation in a renewable energy regime in the Global South.

After this Section 1 (Introduction), Section 2 explains theoretical and conceptual frameworks utilised in this study. Section 3 describes the methodological aspects, such as data collection and data analysis. Then, Section 4 presents the findings from this study, divided into four periods and concomitant fragmentation types of biogas governance in Indonesia. Sections 5 and 6 are discussion and conclusion, respectively.

\section{Theory}

This article draws on the concepts of fragmentation and policy and regime effectiveness, to study the type and impact of fragmentation in the biogas energy regime in Indonesia. The following subsections explain these concepts. 


\subsection{Fragmentation of Regime Complex and Its Output}

A regime complex covers the connection between states' institutions with various non-state institutions and actors related to certain problems [25]. The governance architecture is the overall institutional setting or coordinating structure among institutions and actors within a regime [26]. Studies of fragmentation in regime complexes emerged from the debates about interlocking institutions [27] which analysed linkages across policy domains and the relationships between the different institutions [28]. The distribution of power among institutions within a governance architecture and the interaction of these different institutions are the focus of the fragmentation concept [16].

In the last decade, the fragmentation concept is often utilised for the topics of (global) climate and environmental governance [15]. As a renewable energy, biogas governance can be argued to be part of climate-energy governance. As with any regime complex, the governance architectures of the climate-energy regime are almost never fully interconnected and integrated, and thus, fragmented [11]. In the global climate-energy governance architecture, this fragmentation relates to a lack of interlinkages between institutions, for both state and non-state actors [17]. Such fragmentation is not necessarily problematic and 'diversity' of institutions within regimes is something that can be managed [11].

Biermann et al. [11] categorize three types of fragmentation-conflictive, cooperative and synergistic. Conflictive fragmentation reflects a situation in which there are conflicting principles and rules among the institutions or programs, due to lack of coordination. Cooperative fragmentation occurs when the institutional architecture of state and non-state actors is loosely integrated, due to the existence of actors/organizations that initiate cooperation among each other (Table 1). While in synergistic fragmentation, the governance architecture is well integrated and have synergy in its goal and strategy [11]. In this study, we mainly focus on conflictive and cooperative fragmentation as they are most relevant to the case of Indonesian biogas governance [14].

Table 1. Conflictive fragmentation and cooperative fragmentation within a governance architecture. Source: Author.

\begin{tabular}{ccc}
\hline Origin of theories & $\begin{array}{c}\text { Conflictive Fragmentation } \\
\text { institutions }\end{array}$ & Cooperative Fragmentation \\
\hline Assumptions & $\begin{array}{c}\text { Architectures of governance } \\
\text { are almost never fully } \\
\text { interconnected and integrated }\end{array}$ & $\begin{array}{c}\text { A wide-ranging distribution of power fosters a } \\
\text { policy to include more people or stakeholders } \\
\text { inclusively, performing coordination }\end{array}$ \\
\hline Normative degree & $\begin{array}{c}\text { Some stakeholders agree that } \\
\text { the architecture of governance } \\
\text { must affirm the value of } \\
\text { fragmentation as "diversity" }\end{array}$ & $\begin{array}{c}\text { The diversity of initiatives is the invisible hand } \\
\text { of a market of institutions that results in better } \\
\text { distribution of functions and effects. }\end{array}$ \\
\hline Typical examples & Transnational governance & $\begin{array}{c}\text { Civil society and/or private sectors lead the } \\
\text { governance architecture }\end{array}$ \\
\hline Criteria/indicators & Exclusiveness and incoherence & Distribution of power and cooperation \\
\hline
\end{tabular}

In conflictive fragmentation, there are different programmes with (almost) the same purpose, coming from different policies and different institutions, with unclear governance architecture [15]. Each programme and each institution are exclusive to each other. This regime lacks coordination between these exclusive actors/institutions, so there are overlapping responsibilities and different types of decision makings that cause contradicting and/or incoherent actions [29]. This incoherence hampers priorities to reach substantive goals and primary objectives of the regime, e.g. to improve output or implementation of biodigesters. In addition, it decreases the opportunity for partnerships to be fostered [16]. This conflictive fragmentation sometimes occurs within governmental bodies, and it 
is called administrative fragmentation where the same type of programs is located within various governmental bodies [30].

Cooperative fragmentation has two key advantages which are flexibility and adaptability [31]). It makes the actors have more space to choose the appropriate action, depending on what fits their capabilities. Cooperative fragmentation may accelerate the speed of programs' implementation and trigger innovation. It may also circumvent negotiation stalemates in governments. Specific institutional architectures can better account for specific/contextual situations of preventing problems [11]. The coherence in cooperative fragmentation has the potential to be an enabling factor to increase policy output.

This study looks at historical shifts of configuration in biogas regime to identify forms of conflictive or cooperative fragmentation and how it affects the policy output of biogas programmes. These different types of fragmentation are utilized in this study to understand the problem of low policy output (dissemination number) in biogas governance architecture.

The relationship between the governance fragmentation and policy output links to discussions about regime effectiveness. Regime effectiveness can be assessed in terms of the extent of the regime's performance or achievement of their common objective. The idea of effectiveness implies the notion of regimes or a governance architecture as potential 'tools', where their usefulness in carrying out a task can be evaluated. In adopting this perspective, evaluation of regime effectiveness concentrates on a 'subset' of consequences; those that are relevant to the function of the regime [32]. In this study, the subset of consequences is the output of each biogas program, which, when accumulated, is the collective output of the biogas regime.

To define the output of the regime, policy effectiveness theory is invoked. In policy effectiveness theory, the effects of the (environmental) policy are classified into four types, which are output, outcome, environmental impact, and social needs [33]. Policy output consists of several aspects that include the quantity and quality of the products and/or services delivered by the programme [33]. In this research, the focus is on the effects of fragmented biogas regime on the performance of output in multiple biogas programs which together make up the biogas regime.

\subsection{Conceptual Framework}

This section combines theories and concepts above into a conceptual framework (Figure 1) to guide data collection and data analysis of this study. Figure 1 shows that there are three quadrants representing the regime/governance configuration, which are conflictive fragmentation, cooperative fragmentation, and centralized coordinated. These regime configurations are defined by their characteristics on indicators in Figure 1.

The horizontal axis in Figure 1 depicts the level of distribution of power among institutions within the regime or governance architecture, from centralized to inclusively distributed. Centralized means that there are a smaller number of organizations involved in the regime. Inclusively distributed implies that there are a larger number of organizations within the governance architecture. The distribution of power shows how the resources are distributed among institutions or actors, either centralized (accumulated in few actors) or decentralized (inclusively distributed among actors). To define the resources, we utilised the classification of three types of resources; the authority, finance, and techno-scientific knowledge [14]. These resources affect the ability of institutions in supporting the development and implementation of biogas programs. For example, the distribution of authority, funding, and technical capacity in installing biodigesters allow them to disseminate biodigester to wider communities. Equal distribution of power can occur if there is a division of task and responsibilities among institutions within the governance architecture, and ideally, the task division must be in line with personnel capability of each institution [29]. To have the division of task and responsibility, coordination must happen among institutions to lead to trigger partnership among biogas programmes. 


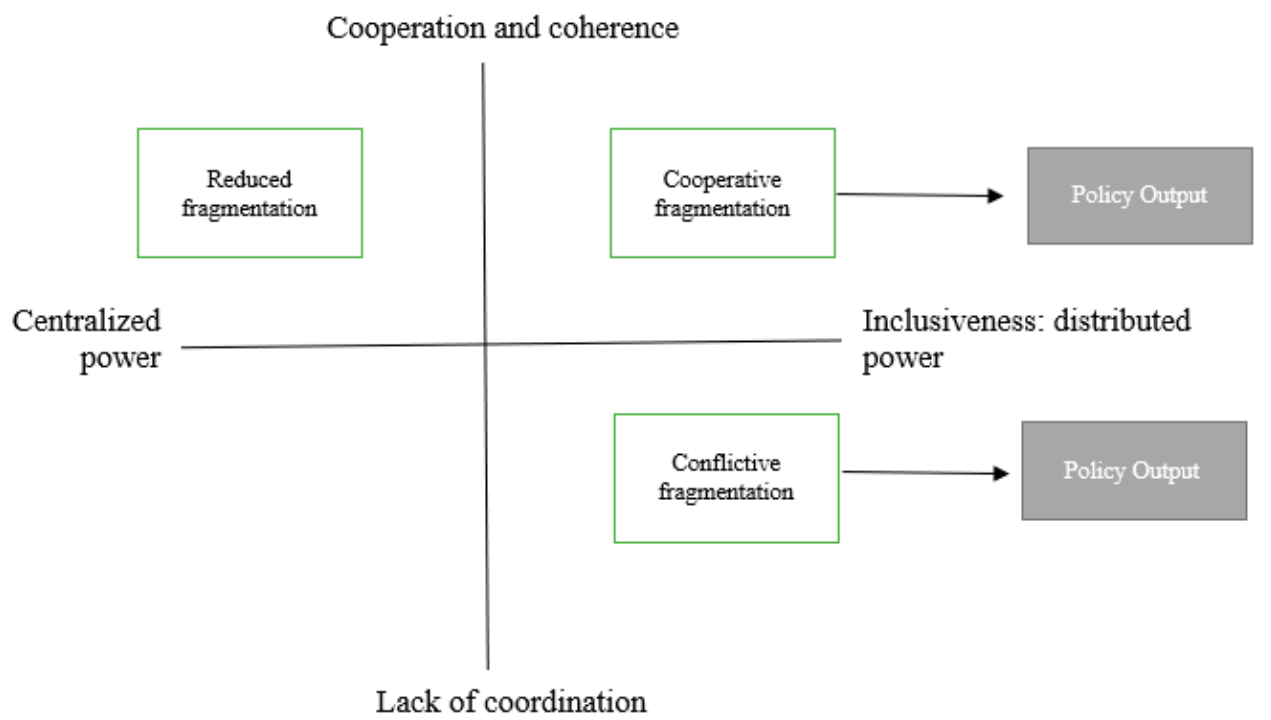

Figure 1. Conceptual framework, adapted from Pahl-Wostl and Knieper [29].

The vertical axis shows the degree of coordination and cooperation among institutions within the regime, from lack of coordination to coherently connected. Lack of coordination means that there is insufficient communication among institutions within the governance architecture, in cooperating to achieve their common goals. While coherently connected is defined as the success of effective coordination among institutions within the regime, that leads into the existence of cooperation and partnership among them in pursuing their common goals, such as increasing dissemination number of biogas technology.

Coordination includes horizontal (across sectors, such as energy to agriculture) and vertical (across administrative levels, such as national to local) coordination. The measure of coordination is examined through how far governance architectures of the biogas programs or regime can facilitate coordination and support collaboration between actors across administrative levels and sectors, such as involving cross-sectoral institutions and local governments. Furthermore, the existence of a coherent piece of the framework that integrates biogas programs is also checked (Table 2).

Cooperative fragmentation regime is characterized by the existence of well-distributed power among institutions. These institutions have a relatively equal distribution of power because they conduct effective cooperation among them and their programs. On the other side, in the conflictive fragmentation regime, there is a lack of coordination among institutions within the regime that often causes a conflict of interest among institutions. Another regime configuration is centralized governance where the power is centralized and coordinated by a single/few institution(s).

In this study, we analyse the landscape of biogas governance architecture in Indonesia from 2007 to 2017, using the abovementioned conceptual framework, examining the possibility of occurrence of different regime configurations; particularly on conflictive fragmentation and cooperative fragmentation. To operationalize the conceptual framework, we draw on the work by Pahl-Wostl, and Knieper [29] to develop a list of indicators to define the situation of 'distribution of power' and 'degree of cooperation' in the configuration of conflictive fragmentation and cooperative fragmentation, in the context of biogas governance (Table 2).

This research aims to find out how the historical changes on the degree of cooperation and distribution of power in the Indonesian biogas regime affects/results in a different impact on the performance of policy output. Policy output is operationalized as the number of biogas digesters disseminated, and the quality of knowledge transfer or information provided through activities, such as training. These indicators are applied to each biogas program and its accumulation from different biogas programs as a biogas regime. For example, information exchange through coordination among 
institutions is considered as cooperation that inspires the institutions to reform their planning and (dissemination) practices on their biogas programme. Furthermore, it could lead to more formal collaboration and partnership between the program or the institutions, to increase output. There is a subset of consequences of such a partnership which creates the incentive-effort-output linkages. The linkages arise when multiple institutions must cooperate and coordinate to achieve policy objectives. In the context of the case study in this research, the policy objectives are to overcome barriers of biodigester dissemination, such as how cooperation among programmes/institutions can shorten bureaucratic processes of dissemination/training activities; accelerating feedstock collection, improving social acceptance by local community, increasing level of priority toward biodigester use; supporting participative monitoring practices and technological maintenance. These activities can be linked to the number of biogas digesters disseminated, and the quality of biogas training, e.g. higher degree of community acceptance toward biogas makes more local people interested in demanding biodigester and its training.

Table 2. Indicators as the topic list (adapted from Pahl-Wostl and Knieper, [29]), which were used to examine configuration dynamics of biogas governance and its policy output in Indonesia.

\begin{tabular}{|c|c|c|c|}
\hline \multicolumn{2}{|c|}{ Regimes } & Conflictive Fragmentation & Cooperative Fragmentation \\
\hline \multicolumn{4}{|c|}{ Aspects and indicators } \\
\hline \multirow{8}{*}{$\begin{array}{l}\text { Governance } \\
\text { architecture }\end{array}$} & \multirow{4}{*}{$\begin{array}{l}\text { Distribution of } \\
\text { power }\end{array}$} & $\begin{array}{l}\text { Involvement of wide-range of } \\
\text { institutions }\end{array}$ & $\begin{array}{l}\text { Involvement of wide-range of } \\
\text { institutions }\end{array}$ \\
\hline & & $\begin{array}{l}\text { No partnerships in } \\
\text { policy/program's planning and } \\
\text { implementation }\end{array}$ & $\begin{array}{c}\text { Extant partnerships in } \\
\text { policy/program's planning and } \\
\text { implementation }\end{array}$ \\
\hline & & $\begin{array}{c}\text { No distribution of } \\
\text { institutionalized functions, } \\
\text { responsibilities, and power across } \\
\text { institutions/programs }\end{array}$ & $\begin{array}{l}\text { Institutionalized functions, } \\
\text { responsibilities, and power across } \\
\text { institutions/programs are } \\
\text { distributed }\end{array}$ \\
\hline & & $\begin{array}{c}\text { No task division in accordance } \\
\text { with the available personnel } \\
\text { capability, across } \\
\text { institutions/programs }\end{array}$ & $\begin{array}{l}\text { Extant task division among } \\
\text { programs, in accordance with the } \\
\text { available personnel capability }\end{array}$ \\
\hline & \multirow{4}{*}{$\begin{array}{l}\text { Coordination and } \\
\text { cooperation }\end{array}$} & $\begin{array}{l}\text { No national biogas-related policy } \\
\text { or plan is coordinated/integrated } \\
\text { (e.g., national biogas plan) }\end{array}$ & $\begin{array}{c}\text { A national biogas-related policy is } \\
\text { coordinated/integrated }\end{array}$ \\
\hline & & $\begin{array}{l}\text { No (in)formal provisions to } \\
\text { support coordination among } \\
\text { organizations across } \\
\text { administrative levels and sectors }\end{array}$ & $\begin{array}{l}\text { Extant (in)formal provisions to } \\
\text { support coordination among } \\
\text { organizations across } \\
\text { administrative levels and sectors }\end{array}$ \\
\hline & & $\begin{array}{l}\text { No significant involvement of } \\
\text { local institutions in biogas } \\
\text { programs or in the creation of } \\
\text { biogas-related institutions }\end{array}$ & $\begin{array}{l}\text { Extant significant involvement of } \\
\text { local institutions in biogas } \\
\text { programs or in the creation of } \\
\text { biogas-related institutions }\end{array}$ \\
\hline & & $\begin{array}{l}\text { Conflict of interest among } \\
\text { institutions }\end{array}$ & $\begin{array}{l}\text { Joint programme, partnership } \\
\text { among institutions in overcoming } \\
\text { dissemination barriers }\end{array}$ \\
\hline
\end{tabular}

Policy output of the regimes

Indicators; The number of biogas digesters disseminated; The amount of information (training) provided.

Multiple institutions can work together to address the dissemination barriers, thus, deliver proper services to the user community. Collaboration among institutions provides formal incentives and relational governance mechanism. This choice of formal incentives and relational governance 
mechanisms depends on the degree of interdependence between the various institutions and its tasks, as well as the observability and verifiability of output [32].

\section{Materials and Methods}

The study draws on semi-structured interviews, reviews of policy and program reports and documentation, as well as academic literature. It includes both quantitative and qualitative data, followed by a series of analyses in relation to the conceptual framework (Figure 2).

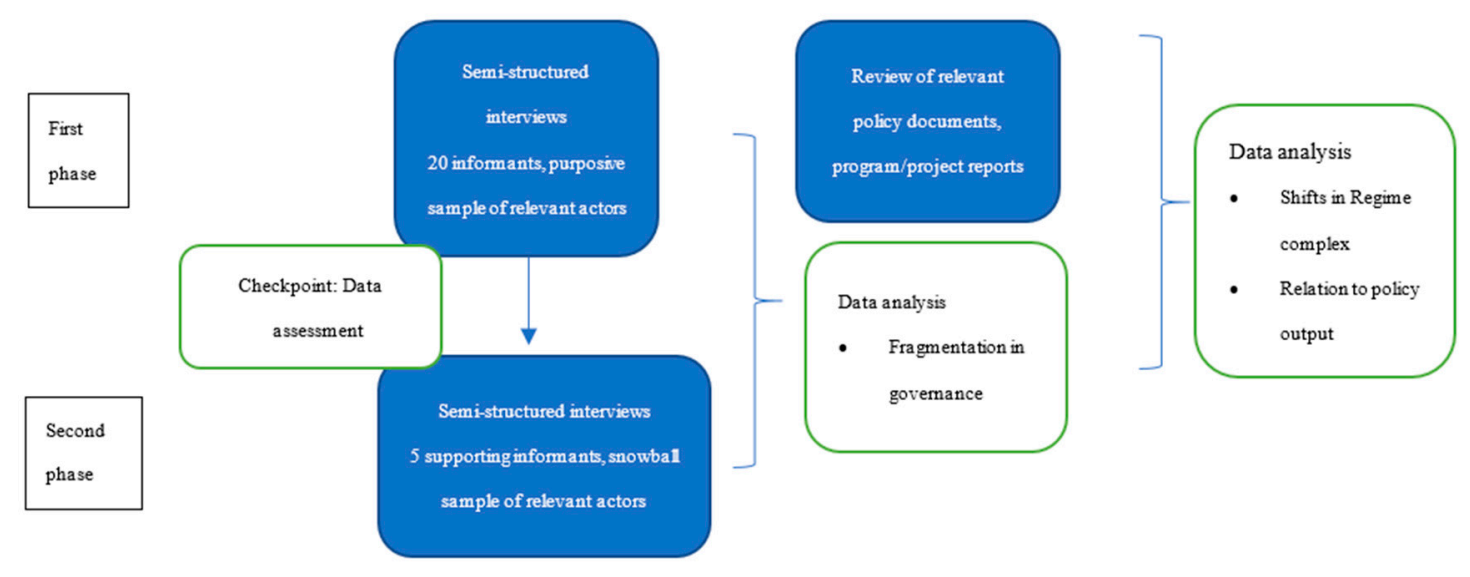

Figure 2. The toolkit of the integrated method and conceptual approach.

In this study, the focus is on the case of Indonesia biogas programs for households and groups (such as farmers groups). These households utilize small-scale biodigesters with the size of $4-6 \mathrm{~m}^{3}$, and the groups utilize medium scale biodigester, sized about $20-40 \mathrm{~m}^{3}$. The biogas programs for households and groups have been established since 2007 in four national-level institutions which are Hivos (an NGO), the Ministry of Energy and Mineral Resources (MEMR), the Ministry of Agriculture (MA), and the Ministry of Environment and Forestry (MEF). These selected cases are equal or sufficiently similar in all dimensions, such as administrative level. These cases are observed with the same approach and in the same period of time, to minimize the variance of potential confounding factors.

Data for this study were collected from abovementioned four key institutions and other stakeholders related to their biogas programs, e.g. other ministries, local governments, businesses, civil society, and academics (Appendix A). A total of 25 semi-structured interviews were conducted from May to July 2018, in two phases (Figure 2). The interviews utilized purposive and snowball sampling technique to select key persons (1-2 people) from the abovementioned stakeholders (See Appendix A). For the interview questions, the topic list from the framework was utilized to guide the interviews. The emphasis was on questions about the link between conflictive/cooperative fragmentation with the policy output (of the regime). Each interview had a duration of approximately one to two hours, and were carried out face-to-face, mostly in the offices of the respective institutions. During each interview, policy and program reports, as well as documentation regarding biogas programs, were requested from each stakeholder, to be reviewed for triangulation (See Appendix B).

After collection, all data were organized to prepare the structure of the evidence, based on the conceptual framework (Figure 1) and its indicators (Table 2). Depending on the nature of the data, they were transcribed (in case of interviews), scanned (in case of document and literature review) or typed up (in case of other field notes). Later, for a more detailed analysis, a coding process was undertaken. The first coding session was done on the interview transcripts, policy documents, and program/project reports to analyze governance arrangements from each biogas program and its institutions. Afterwards, the second round of coding was done to analyze the distribution of power and degree of coordination among biogas programmes and its institutions within the biogas regime. This analysis helped to 
construct an overview of the governance architecture and the type and degree of fragmentation in the biogas regime.

A third coding round then analyzed the relationships between the fragmented governance architecture related to the policy output of the regime. To minimize the influence of confounding factors in this analysis, each relationship between each indicator in the distribution of power, degree of cooperation, and policy output was carefully reviewed and triangulated from the interview transcripts, policy documents, and program/project reports. In each relationship analysis, we considered the role of potential confounding factors. This helped us to categorize the time periods of regime change. In addition, the criteria for categorizing the time periods was also based on considerations of (1) data availability from data collection, and (2) data analysis based on indicators within each type of fragmentation.

\section{Results}

Our findings allow us to distinguish four shifts of biogas regime configurations in Indonesia during the period of 2007 to 2017 (Figure 3). Fragmentation of biogas governance occurred from 2007-2016 to different extent: Administrative fragmentation from 2007 to 2009; conflictive fragmentation from 2010 to 2013; and (limited) cooperative fragmentation from 2014 to 2016 (Figure 3). The different levels of fragmentation within each period affected the policy output of biogas governance architecture in Indonesia in different ways (Table 3 and Figure 4). As mentioned, two key forms of output are considered in this article: The number of biodigesters disseminated and the number and quality of training to biogas users, by the various biogas programs. This collective output from the biogas regime is explained below and summarized in Table 3 and Figure 4.

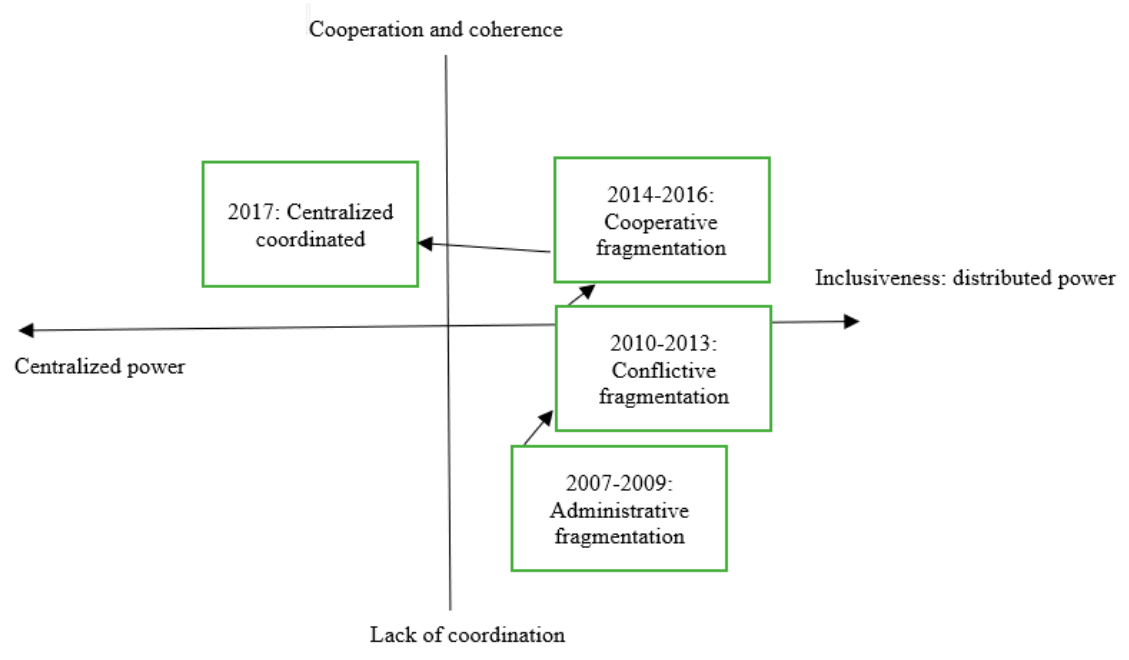

Figure 3. Periodical changes in the configuration of biogas governance architecture.

Table 3. Main situation changes in the configurational shifts of biogas governance architecture.

\begin{tabular}{ccccc}
\hline Year Period & 2007-2009 & 2009-2012 & 2013-2016 & 2017 \\
\hline $\begin{array}{c}\text { Regime } \\
\text { configuration }\end{array}$ & $\begin{array}{c}\text { Administrative } \\
\text { fragmentation }\end{array}$ & Conflictive fragmentation & $\begin{array}{c}\text { (Limited) } \\
\text { cooperative } \\
\text { fragmentation }\end{array}$ & $\begin{array}{c}\text { Reduced } \\
\text { fragmentation }\end{array}$ \\
\hline Situation & $\begin{array}{c}\text { Various ministries } \\
\text { competed for the } \\
\text { budget for biogas } \\
\text { programs }\end{array}$ & $\begin{array}{c}\text { NGOs (Hivos and YRE) } \\
\text { cooperated with the MEMR } \\
\text { (Ministry of Energy), SWEN } \\
\text { (biogas company) worked } \\
\text { with the MA (Ministry of } \\
\text { Agriculture) }\end{array}$ & $\begin{array}{c}\text { BIRU extends the } \\
\text { collaboration } \\
\text { with other } \\
\text { government } \\
\text { biogas programs }\end{array}$ & $\begin{array}{c}\text { Government } \\
\text { biogas programs } \\
\text { are centralized } \\
\text { under the MEMR }\end{array}$ \\
\hline
\end{tabular}




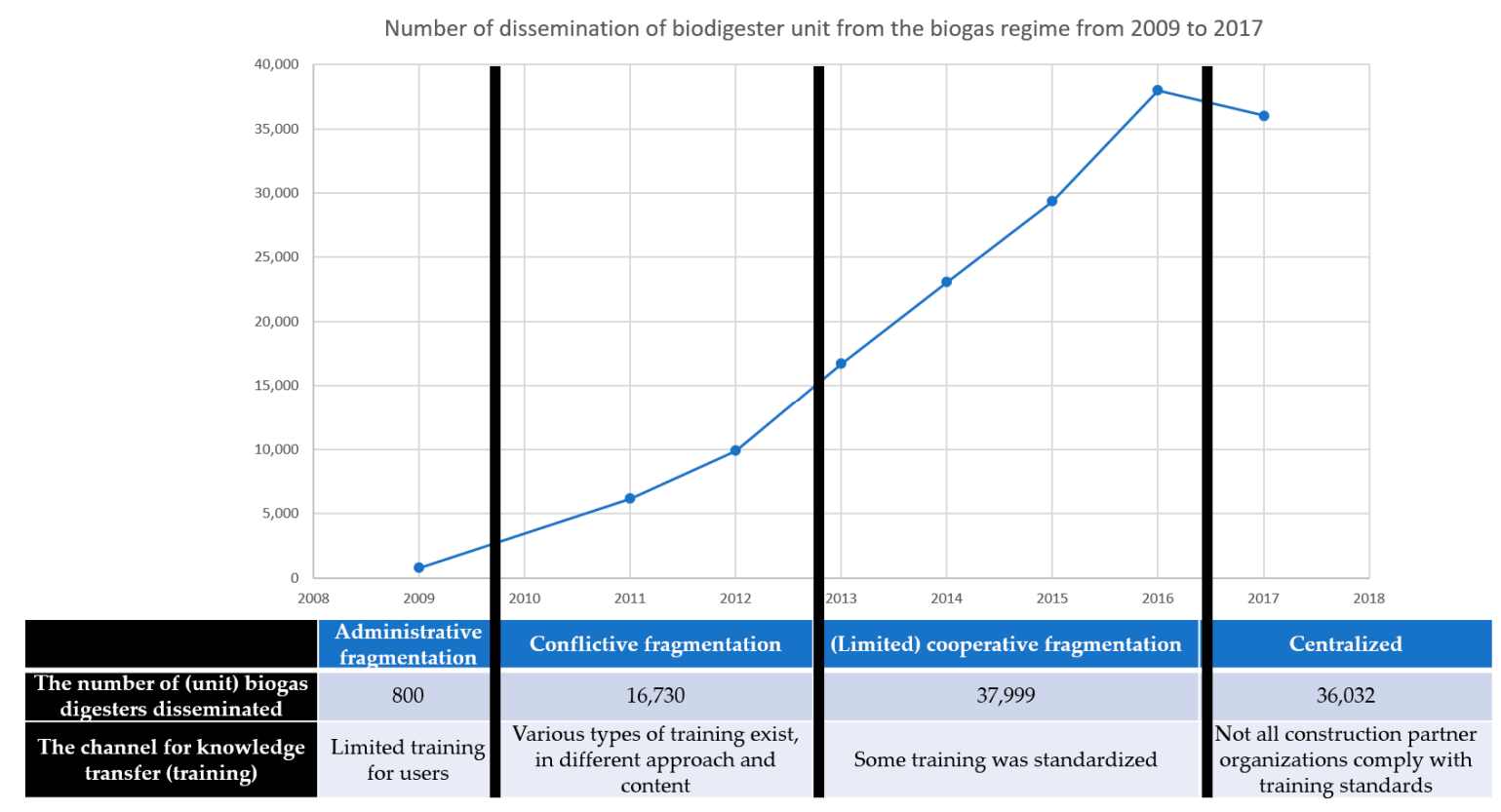

Figure 4. The policy output of biogas programs in four fragmentation periods, the increasing degree of cooperation is aligned with the rate of rise of biodigester dissemination and knowledge transfer activities (Source: Author's data analysis; [34,35]).

The following sub-sections elaborate on how the dynamics within the fragmented biogas regimes are related to policy output in different periods.

\subsection{Administrative Fragmentation (2007-2009)}

From 2007-2009, biogas programs were dominated by the government bodies, without significant participation by non-state actors (Figure 5). At that moment, biogas programs were directed by different regulatory policies, such as national energy planning in the MEMR (Ministry of Energy and Mineral Resources), integrated agriculture in the MA (Ministry of Agriculture), and ecosystem conservation in the MEF or Ministry of Environment and Forestry (Bappenas, Personal Communication, June 2018). These regulations led various ministries, including the MEMR, the MA, and the MEF to having different biogas programs in their ministry. The MA even had two different biogas programmes in different directorates, which are in the Directorate of agriculture infrastructure and in the Directorate of Livestock (TFCC MA, Personal Communication, June 2018).

This situation can be characterized as a regime of administrative fragmentation where different government bodies have the same type of programs, and limited coordination takes place. The absence of integration was caused by the lack of overarching regulation to facilitate coordination among those biogas programs. In this situation of conflicting roles to disseminate biodigesters, those different institutions competed for a bigger share in national budget planning for their own biogas programs. Those biogas programmes often had similar characteristics, and biodigesters were generally provided for free for the communities.

The absence of coordination among the MEMR, the MA, and the MEF became the obstacle for initiating a partnership for reaching optimum output from the biogas programmes. An implication of the administrative fragmentation in the 2007-2009 biogas regime to the policy output can be seen in the data available about the dissemination of biodigesters and the quality of the training to the users. For example, there was no reliable or integrated data by the government about the number of biodigesters from the biogas programs in the period of 2007-2009. Instead, data was scattered. For example, the MEMR and the MEF had actually lost the data, due to poor archiving (MEF, Personal Communication, June 2018). From the Ministry of Agriculture (MA), it was reported that 952 units 
of biodigesters were disseminated from 2007 to 2010 (MA, Personal Communication, June 2018; Appendix B). These governmental biogas programmes worked with SWEN, a biodigester-producer company. With the data from the MA, we can estimate that about 800 biodigesters were disseminated until 2009 (Table 2).

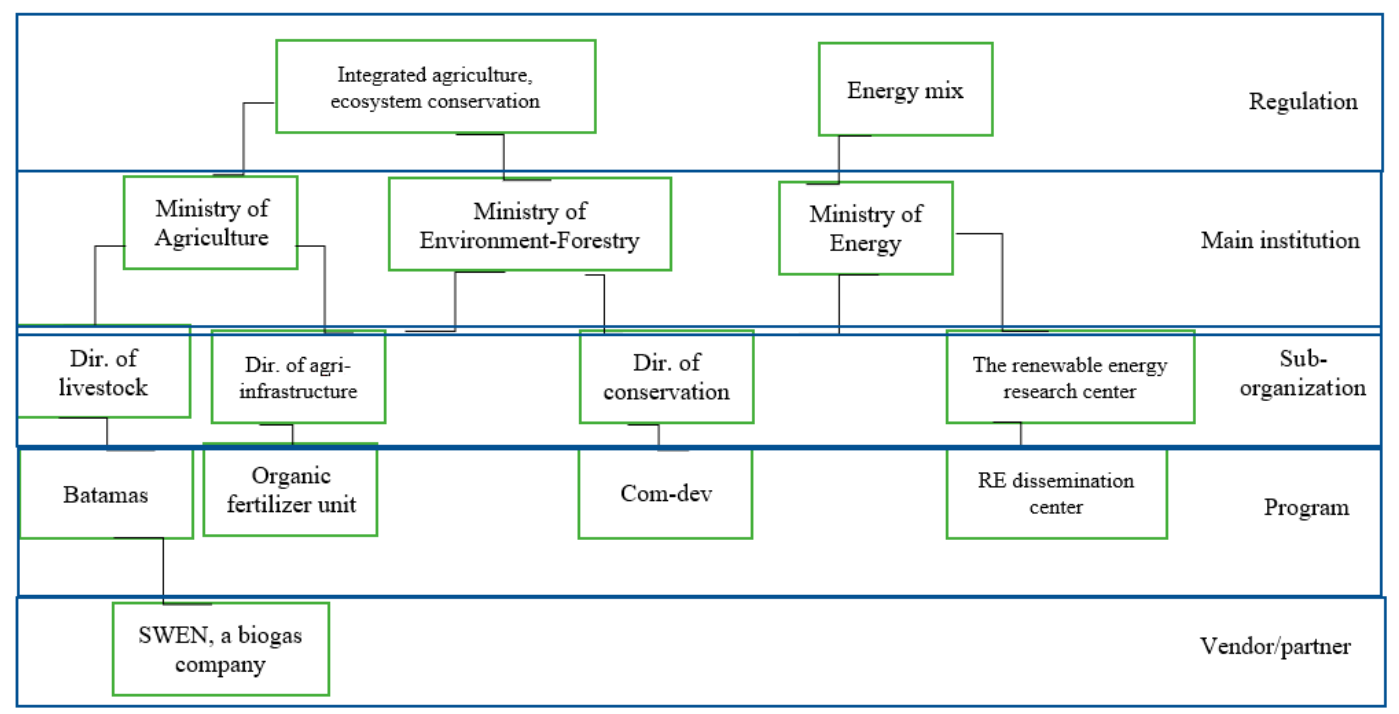

Figure 5. The governance architecture of biogas regime in 2007-2009, various biogas programs in Table.

For the output of training, the MEF and the MA claimed that they provided pre-training to the biogas users. However, this training was conducted with limited resources from the government and limited time availability by the users. The ministry let the vendors, or third parties provide the training, and there was no comprehensive monitoring and evaluation (M\&E) from the ministry for the implementation of the digester dissemination and the training (MA, Personal Communication, June 2018).

\subsection{Conflictive Fragmentation (2010-2013)}

In 2009, Hivos (an international NGO) entered the biogas regime by establishing a biogas program called BIRU or Household biogas project (Hivos, Personal Communication, June 2018). In addition, new programmes appeared in the MEF and the MEMR (Figure 6). BIRU developed a partnership with the MEMR biogas programme in 2010, which increased the level of priority of biogas in energy mix targeted by the MEMR. Likewise, many local governments also have their own biogas programs, which were not always linked to the national biogas programs (Energy agency-West Java, Personal Communication, June 2018). The emergence of these new biogas programmes shows that power was more distributed among various actors within the biogas regime, compared to the period 2007-2009. Table 4 and Figure 6 depicts the situation of biogas governance architecture in Indonesia in 2010-2013, with more detail on each program and its implementing agencies from NGO and the directorates under the MEF, the MA, and the MEMR. 


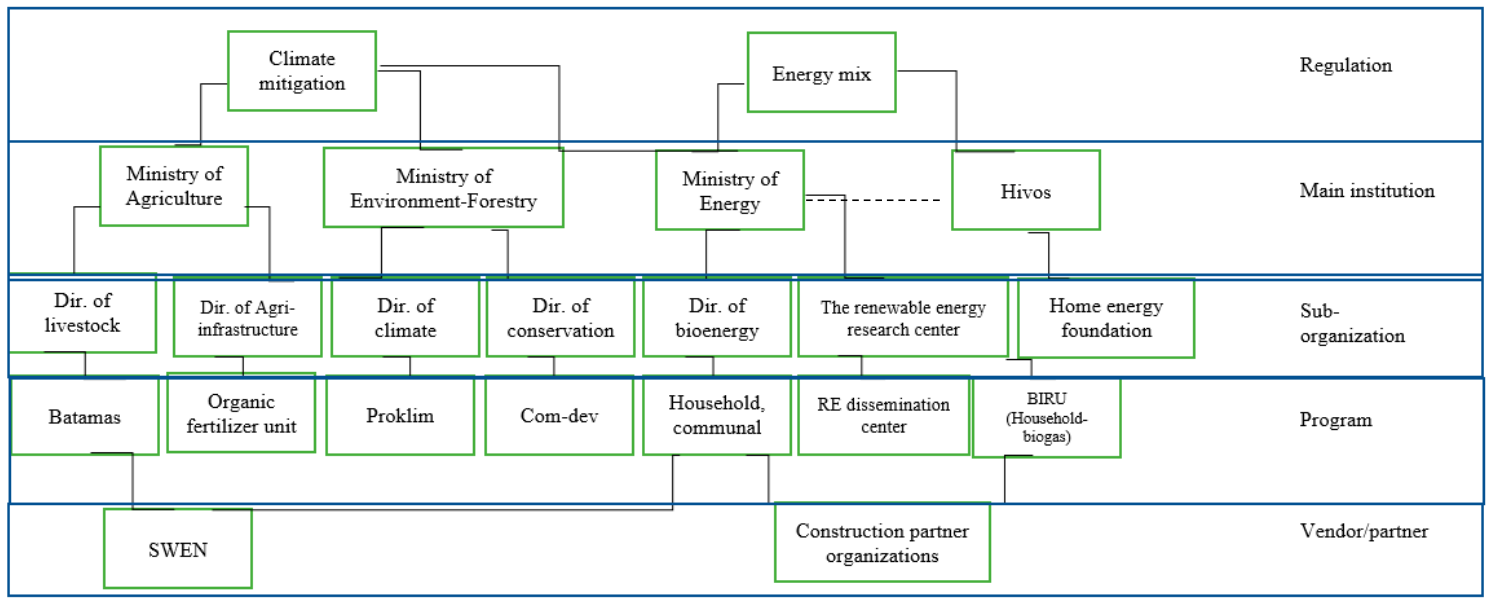

Figure 6. The emergence of new institutions and programmes, as well as the partnership between the Ministry of Energy and Hivos-in the architecture of biogas governance in Indonesia, triggered a new dissemination approach and accelerated speed of implementation.

Table 4. Synthesis of the regime situation from 2010 to 2013. MEMR, Ministry of Energy.

\begin{tabular}{ccc}
\hline Distribution of power & 2010-2011 & 2012-2013 \\
\hline $\begin{array}{c}\text { Coordination and } \\
\text { cooperation }\end{array}$ & $\begin{array}{c}\text { Hivos entered the biogas } \\
\text { powner in the regime }\end{array}$ & $\begin{array}{c}\text { Hivos established YRE (a local NGO), it } \\
\text { MEMR through BIRU programme } \\
\text { increased the distribution of power within the } \\
\text { governance architecture }\end{array}$ \\
\hline $\begin{array}{c}\text { Policy output of the } \\
\text { regime }\end{array}$ & Dissemination number increased & $\begin{array}{c}\text { TRE tried to expand BIRU cooperation, but } \\
\text { hampered by competition with SWEN and MA }\end{array}$ \\
\hline
\end{tabular}

Figure 6 shows that each ministry had more than one biogas program. For example, in the MEMR, the Renewable Energy Research Center (RERC) had their own biogas program, separate from the biogas programmes in the Directorate of Bioenergy (RCRE MEMR, Personal Communication, June 2018).

This increase in fragmentation had a number of underlying reasons. First, on the government side, each ministry had different motivations to carry out their biogas programs (MEF, Personal Communication, June 2018). For the MA, the main motivation was to improve the management of agriculture waste through managing cattle manures through activities, such as composting and generating biogas. For the MEMR, the biogas program aimed to reduce the cost of subsidy for kerosene and LPG and to achieve a renewable energy target. For the MEF, the biogas program had as key objectives to (1) conserve the forest, by providing alternative energy sources (replacing firewood) for the community surrounding forest, and (2) to reduced emissions by introducing biogas as part of climate action (Bappenas, Personal Communication, June 2018).

The second reason was the lack of coordination among institutions and unwillingness to integrate their different motivations. This lack of coordination was influenced by 'institutional ego' and hierarchical structures that hampered the regime in moving towards common goals. Institutional ego is the selfish attitude of an institution that avoids cooperation. Institutional ego led state actors do not participate in common agreements within the governance architecture of the regime [11,23].

For instance, the MA only wanted to come for a coordination meeting if the invitation came from a higher ministry, such as the MDP (Ministry of Development Planning) or the MM (Ministry of Coordinator of Maritimes) as this quote aptly illustrates: "The coordination should be held by the MDP or the MM because they have more power and authority in the government architecture, not by the MEMR or the MEF" (MA, Personal Communication, June 2018, translated from Bahasa). In addition, the MA refused to provide biogas data to the MEF who gathered data on emission reduction from 
biogas (MEF, Personal Communication, June 2018). Finally, the lack of coordination also resulted from a lack of priority given by the central government to biogas. Many ministries simply had no time to perform coordination, due to other (higher priority) tasks they had to accomplish (MEF, Personal Communication, June 2018).

In the period of 2010-2013, governmental biogas programmes were somehow divided into two groups, one from SWEN that worked mostly with the MA and another one from BIRU that worked mostly with the MEMR (SWEN, Personal Communication, June 2018). This relates to the third reason for the fragmented nature of the regime. BIRU and SWEN had different views about the ideal biogas technology, its market development, and the approach to maintaining biodigester quality (YRE, Personal Communication, June 2018; SWEN, Personal Communication, June 2018). BIRU argued that fixed-dome digesters were a strong technology and proven in other developing countries, while SWEN believed that the floating drum (fibre digester) type was more suitable for Indonesia's earthquake-prone geography. Furthermore, BIRU developed the biogas market and its actors by providing training to hundreds of local organizations and to distribute techno-scientific information about biogas digesters. These organizations then become BIRU's construction partner organizations (CPOs) that played a key role in installing biodigester on the ground, in Indonesian villages. By contrast, SWEN tended to monopolize the biogas market as a way to maintain the quality of biodigesters disseminated.

The promotion strategy also differed between SWEN and BIRU. Both used the grant approach, where they work as a vendor to the government that pays for a free biodigester for the community. They differed in the commercial approach in which BIRU and SWEN were selling biodigesters to communities or groups. In the second approach, BIRU provided 30\% subsidy in the sale. This subsidy came from carbon markets and development funds from international donors, as well as the MEMR. The commercial approach removes the barrier of bureaucracy process in biodigester dissemination.

The contradicting ideas and principles between BIRU and SWEN, thus, reflected a situation of conflictive fragmentation. The diversity of strategies a result of a situation of fragmentation that brings out the diversity and new innovations, in this case to biodigester technology and approach of its dissemination.

In 2012, Hivos established YRE (Home energy foundation) as a national NGO to continue leading the BIRU program and to train more CPOs (Hivos, Personal Communication, June 2018). As such, BIRU distributed their power to non-state actors. While the cooperation of BIRU with the government was still limited to the MEMR, other ministries, such as the MA and the MEF still continued their own biogas programs, with a majority of these collaborations with SWEN as their dominant vendor (SWEN, Personal Communication, June 2018). At that moment, there were no an 'agents of change' that could support the wider collaboration among actors.

This conflictive fragmentation regime continued between SWEN group and BIRU group until 2012. SWEN wanted the government to heavily subsidise biogas dissemination (SWEN, Personal Communication, June 2018), while BIRU had figured out that the grant approach had become an obstacle to their commercial approach. Indeed, some people refused to purchase BIRU digesters because they expected free digesters from the government (YRE, Personal Communication, June 2018). In other words, there were conflicting ideas between BIRU's commercial approach and a system of governmental grants. This conflict comes back in the next period (see Section 4.3).

Despite the conflicts, there were no discussions between BIRU and SWEN. Nor was there any coordination and cooperation initiated by other actors to facilitate communication between SWEN group and BIRU. The difference remained a hidden source of conflict within the fragmented biogas regime, in which each group wanted to keep the (highest) benefits or budget for their own biogas program, and to discourage efforts to facilitating coordination.

Despite the conflict, BIRU kept trying to intensify their partnership with the MEMR, in which BIRU derived more donors and the MEMR gained more budget for biogas programs. In turn, this led to more money being available for biogas dissemination and to an increasing number of biodigester disseminated. BIRU's strategy to train CPOs also created more expertise at biogas builders (SB. Utama, 
Personal Communication, June 2018). From 2010 to 2013, the total number of disseminated biodigesters was around 16,000 units [36]. BIRU had installed about 11,000 digesters, the MEMR disseminated around 4000 digesters, and the rest came from other programs in the MA and the MEF. BIRU and the MEMR, thus, contributed significantly to accelerating biodigester dissemination, but the establishment of BIRU and the cooperation with MEMR also increased the degree of fragmentation to biogas regime (DB MEMR, Personal Communication, June 2018).

The situation of conflictive fragmentation also seemed to slow down the rate of disseminated biodigesters since the government grant system was slowing down the promotion of commercial biodigesters by BIRU and SWEN, as users preferred for free biodigester from the government (Hivos, Personal Communication, June 2018). In addition, there were conflicts about overlapping dissemination locations between different biogas programmes, due to the lack of coordination. This issue hampered the opportunity to wider disseminate biodigesters. To solve this, the MA planned to develop a database to avoid overlap of biodigester grants in the same location (TFCC MA, Personal Communication, June 2018). However, to date, this has not happened.

The fragmentation also influenced the provision of training in biogas programs. Specifically, it led to the existence of various types of training, which were aligned with the different approaches and technologies by each biogas programme. BIRU's training was followed with six months after-sale services (Hivos, Personal Communication, June 2018), while the government biogas programs only provided randomized training, without the certainty of services after installation (MA, Personal Communication, June 2018).

\section{3. (Limited) Cooperative Fragmentation (2014-2016)}

In 2013, Hivos and YRE tried to extend BIRU's collaboration with other government biogas programs in the MA, the MEF, and local governments. This decision was motivated by a wish to increase the number of biogas digesters and to increase the quality of digester technology (YRE, Personal Communication, June 2018). This move affected the fragmentation degree in the biogas regime, moving slightly from conflictive towards the direction to cooperative fragmentation. Many local governments welcomed BIRU's approach and integrating it to their local biogas programs. Compared to biogas projects from ministries, these local biogas programmes have a shorter bureaucratic process. Some government bodies henceforth started to have a formal partnership with BIRU; this increase level of priority of biogas in the development plan of local governments. The partnership with local government made the governance architecture was slightly more integrated, compared to the previous period, before 2014 .

Competition still remained between supporters of BIRU (the MEMR and local governments) and clients of SWEN (the MA), yet some of their different principles started to change. Both parties kept their own technological preference, but also started to diversify their business approach. After 2013, SWEN did not only rely on the government grants, but also actively promoted their products to wider markets, including companies and individual users (SWEN, Personal Communication, June 2018). Meanwhile, BIRU started to compromise with the government grant approach by modifying the scheme of governmental biogas programme. BIRU proposed that the government to change the full subsidy scheme into partial subsidy (SB. Utama, 5 June 2018). This proposal was accepted by several local governments, such as in West Java and West Nusa Tenggara province (AABR, Personal Communication, June 2018). BIRU also initiated partnership with local farmers groups to speed up feedstock collection for biodigester (KPSBU, Personal Communication, July 2018). Addition of more local governments and farmers groups into the biogas regime increased the degree of distribution of power within biogas governance architecture. It provided equal access to opportunities and resources for more actors involved in biogas dissemination.

Despite the increased inclusiveness within the 2014 biogas regime, substantive coordination and cooperation was still a problem between BIRU and SWEN as both parties refused to start communication and preferred to continue the competition. This is illustrated by the following quotes: 
We tried to cooperate with BIRU, but it just did not happen because we have different technology and approach, (SWEN, Personal Communication, June 2018, translated from Bahasa)

They (SWEN) uses different technology (fibre digester) and works a lot with many government projects. I am curious about their motivation and vision, (YRE, Personal Communication, June 2018, translated from Bahasa)

On the public-sector side, the government bodies also did not effectively coordinate and cooperate across sectors and levels. There was no significant cooperation between biogas programs in the MEMR, the MA, and the MEF (Bappenas, Personal Communication, June 2018). According to the MEF (Personal Communication, June 2018), and the MA (Personal Communication, June 2018), coordination about biogas programs should be facilitated by the Ministry of Economic Coordinator, according to a hierarchical structure. However, it did not happen. Instead, one coordination meeting about biogas programs was organized by the Ministry of Maritime Coordinator with the MEMR and the MA to endorse biogas programmes (MCM, Personal Communication, June 2018). As a result, cooperation among governmental biogas programmes was still very limited.

Nevertheless, coordination of BIRU and SWEN with more government bodies from 2013 to 2016 seemed to positively affect the output of biogas programs. In this period of a limited cooperative fragmentation regime, the number of biodigester units more than doubled in three years, from about 16,730 in 2013, to 37,999 in 2016 [36]. Compared to the increase rate (3729/year) in the period of conflictive fragmentation, the rate of increase in this cooperative fragmentation regime was also significantly higher, with 7027/year.

The cooperation also affected the quantity and quality of training for users in biogas programs. BIRU set the standards for the training and implemented the training in different biogas programs where they had partnerships (Y Kontak, Personal Communication, June 2018). The training was delivered through construction partner organizations, who transferred the knowledge to the biogas users. These CPOs applied the same standards when they worked with other biogas programs from the ministries and local governments (CPO, Personal Communication, June 2018). Interaction among these actors, thus, triggered more distribution of techno-scientific knowledge across different biogas programmes.

The distribution of resources (authority, finance, techno-scientific knowledge) in the biogas governance architecture allowed different institutions to test new innovations, to improve the speed of project implementation and to accelerate the dissemination of biodigesters. Some biogas programs managed to have partnerships and joint responsibility in monitoring and evaluation, sharing funding, and exchanging techno-scientific knowledge for improving social acceptance toward biogas. This cooperation contributed to an increase in the policy output of the biogas regime.

\subsection{Reduced Fragmentation: Centralization (2017-2018)}

In 2017, the central government issued an instruction to unite all governmental biogas programs under the MEMR (DB MEMR, Personal Communication, June 2018):

From 2017, there are no more other ministries having biogas programs, because all (biogas programs) are moved to (under) DAK or SAF (special allocation fund scheme), below the MEMR. This decision was confirmed by the presidential office to follow national policy about one data policy. (DB MEMR, Personal Communication, June 2018, translated from Bahasa)

The so-called Satu Data ('One data') Policy is designed to improve internal government data governance practices by providing a regulatory framework concerning organizational structure, including the roles, tasks, and responsibilities of each key stakeholder. It aims to integrate similar programs under the coordination of one ministry, to help the government to collect data about the program (DB MEMR, Personal Communication, June 2018). The implementation of this policy had important implications for the biogas programs in the MA and the MEF, which quickly getting smaller 
and disappearing in the period 2017-2018 (DL MA, Personal Communication, June 2018). In this situation, the power of authority in government biogas programs shifted almost completely to the MEMR, which reduced the degree of fragmentation within biogas governance. This change left only the MEMR, BIRU, and the local governments in the biogas regime, and thereby decreased the distribution of power in the biogas governance architecture (Figure 7).

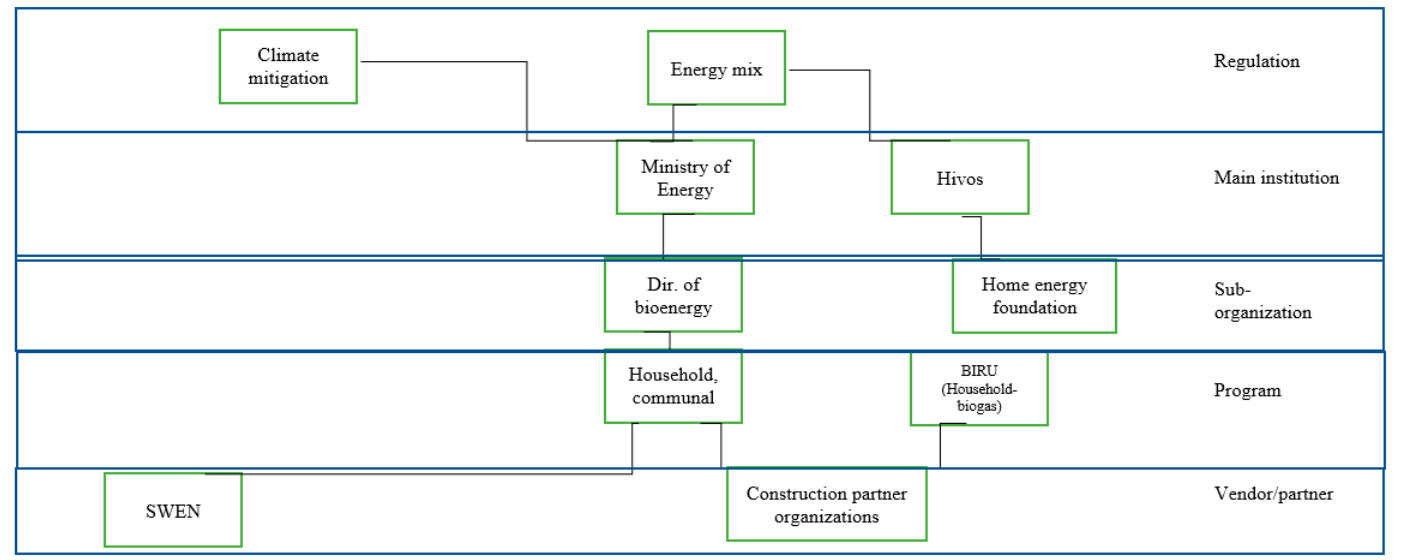

Figure 7. Reduced distribution of power in governance architecture of biogas in 2017.

The MEMR claimed that the centralization plan aimed to ensure the quality of biogas and to align it with the national standard (DB MEMR, Personal Communication, June 2018). However, at the time of field observation of this research in 2018, there was no proof of this. Instead, the centralization reduced the biogas program output from about 37,999 in 2016 to 36,032 in 2017 [36]. About 1000 biodigesters are estimated to be excluded from maintenance as the centralization of power led some institutions to reduce their efforts to maintain existing biodigesters. Furthermore, the budgets for biogas programs in the MA and the MEF were reduced by the Ministry of Finance (DL MA, Personal Communication, June 2018), which also affected the existence of training in their biogas programmes. Since 2017, the MEF no longer covered the budget for training in their biogas-related program, and the MA had only a limited budget for the training (DCC MEF, Personal Communication, June 2018). This lack of resources had consequences for the ability of programmes to comply with training standards (YRE, Personal Communication, June 2018) and it reduced the quality of the information received by the users, e.g. on maintenance.

This policy change, thus, stopped the transition of the biogas regime towards more cooperative fragmentation. In this case, the centralization of biogas programmes was a step back from cooperative fragmentation and changed the distribution of power within the biogas regime. This resulted in a decline of efforts to disseminate biodigesters, and thereby a reduction of the number of biodigesters. The centralized power declined the opportunity for cross-sectoral collaboration and information exchange across institutions. While the MEMR argued that centralized biogas governance aimed to enforce compliance with the national standards (DB MEMR, Personal Communication, June 2018), the lack of effective M\&E of biogas programmes of the MEMR makes this doubtful.

\section{Discussion}

This research discusses the relationship between different types of regime fragmentation and its policy output at the national-level. The main findings are as follows:

- The biogas regime in Indonesia underwent a transition from administrative, via conflictive to cooperative fragmentation from 2009 to 2016, which contributed to the rise of biodigesters disseminated.

- Within this transition, non-state actors (NGOs and companies) were key to cooperate with multiple government bodies, business actors, and local organizations. Some stakeholders accepted to 
collaborate (cooperative fragmentation), while some rejected, due to conflicts of interest (conflictive fragmentation).

- A transition to cooperative fragmentation occurred in 2013-2016, where there had been an increase in the distribution of power and degree of cooperation within the biogas regime. BIRU's decision to start partnerships with various government programs and various funding sources contributed to increase in the number of biodigester dissemination and quality of training activities.

- In 2017, the cooperative fragmentation regime was transformed into a centralization model that reduced the distribution of power within the regime, followed by the decline of its policy output.

The gradual rise in the distribution of power meant that the biogas governance architecture developed into a more inclusive regime. Over time, the degree of cooperation increased in a previously fragmented biogas regime. From 2009-2016, there was more advanced coordination, information sharing, natural collaboration, and formal partnerships among biogas programs within the regime. This change indicates a possibility to upgrade the governance architecture to synergistic fragmentation with a better distribution of functions and effects within the regime.

Nevertheless, while coordination among biogas programs was actually improving in 2016, the policy change towards centralization in 2017 altered the biogas governance architecture completely. Conflicts about data and funding appear to be resolved, but not in the logic of the synergistic fragmentation. The national government resolved it by centralizing all power. It reduced the distribution of power within the regime abruptly and thereby also stopped the move towards more cooperative fragmentation.

The choice of centralization as a means of conflict resolution by the Indonesian government might be caused by a misinterpretation of the logic of coordination within the One Data policy. If the government interpreted it by creating a coordination setting in decision-making that has a certain degree of autonomy to support experimentation and learning [37], then it may change the biogas governance architecture to be more cooperative fragmentation. Instead of creating a centralized coordination setting, the national government chose to integrate related programs into one project. This decision can be considered to be caused by the institutional ego. This institutional ego created competition among institutions instead of coordination. Additionally, a combination of fragmentation and (economic) competition might result in the general decline of regime output. This so-called 'race to the bottom' drives the regime away from synergistic fragmentation [11,13].

To avoid a race to the bottom, the regime progress in 2016 should have been focused on synchronizing cooperation among biogas programs and its actors. The MEF (DC, Personal Communication, June 2018) suggested that biogas programs in Indonesia should be connected by creating synergy among the ministries. The base should be the existence of $70 \mathrm{~K}$ villages as a joint target for disseminating renewable energy. For example, in 2019, the MDP, the MEF, and the Ministry of Villages should lead the coordination to divide the responsibility among the ministries, such as the MA and the MEMR, to work on different villages. For the MEF, there are 2700 villages in surrounding the forest and 6000 villages near conservation areas. However, this synergy requires the willingness of the leaders in each ministry and the country itself (DC MEF, Personal Communication, June 2018).

In addition, there are also other themes that can be used to establish coordination for biogas programs, such as the rural economy and environmental action (EAWJ, Personal Communication, June 2018). Those themes can be used by the biogas regime to increase the degree of cooperation and the policy output of a biogas regime for energy provision and environmental action. Such a direction can concretely improve the biogas governance architecture towards better policy output and more effective performance.

This study has showed the approach to work back from the observed outputs of a fragmented regime and built the case for linking these with changes in the various regimes. The use of qualitative methods in this context provided several merits. First, it provides a deeper and more detailed analysis by focusing on attitudes and behaviors of institutions/actors. Second, it encouraged interviewees to expand on their responses and open up new topic areas which were not initially considered. As such, 
it enabled us to identify the presence of potential 'confounding' variables, such as the unique role of non-state actors (e.g. SWEN) in the regime and their contribution to policy output. The interviews showed that the different dissemination approaches (through grants or commercial) have more to do with sticking to existing positions, rather than to some objectively 'better' approach. This directly impacted the number of biodigester disseminated. Third, it created the possibility of triangulating different sources of information, e.g. policy/project documents with the interviews.

This study shows how regime configuration (distribution of power/resources and interaction among them-coordination, cooperation, collaboration, and partnership) affected policy output. While we can make plausible claims about mechanisms linking output and regime configurations, there may well be other (confounding) factors which we did not cover or get less attention in this study as a result of our selection of interviewees and our interpretation and analysis of the data.

The governance of biogas in Indonesia resonates with other examples in the field of renewable energy. The global renewable energy landscape, for example, consists of the International Energy Agency (IEA), the UNFCCC, the CSD, UN-Energy, SE4ALL, and several global partnerships, initiatives, and forums. However, these actors developed effective cooperation and established IRENA as an institutional home that created a hub where the scattered initiatives can gather, exchange information and generate synergies [38]. In cooperative fragmentation, specific actors remain outside of the main governance architecture, but maintain coordination and cooperation. They remain outside because most initiatives acknowledge the process of the main governance architecture, but many do not provide a coordination mechanism that could ensure mutual compatibility [11,23].

Beyond energy regimes, in large river basins in Europe, Africa, and Asia, the lack of effective cooperation across sectoral and administrative boundaries was identified as an important barrier for climate action [39]. Without effective coordination, the distribution of power overlaps with responsibilities in different decision-making centres. This situation creates contradicting actions with loss of effectiveness and efficiency [40].

The discussions about cooperative fragmentation link to the concept of polycentric governance, which has received much attention in recent literature [37,41-43]. In short, polycentric governance originates from the concept of polycentric systems for implementing policy and governing a particular problem in an area. An ideal polycentric system is multi-level and involves various actors [44]. Such systems may even consist mainly of civil society and private actors, 'leading' the governance architecture [45]. The polycentric regime has various 'centres' at different scales that each may independently create and enforce rules for a specific area. Some units may be self-organized as NGO or parts of local governments system [46].

Polycentric governance is comparable to cooperative fragmentation because both involve a wide-ranging distribution of power that fosters inclusion of people and stakeholders [29]. Those stakeholders perform effective coordination and cooperation across various levels. Such coordination is likely in the cooperative fragmentation regimes that have loosely integrated institutional architectures [29,47].

The concepts of (cooperative) fragmentation and the polycentric regime are a diversity of initiatives or 'the invisible hand' of a market of institutions [12]. The power structures in the regime are often adaptive, flexible, and vastly experimental [48]. This study proves that those concepts are useful in understanding the distribution of functions and effects in the regime complex of renewable energy. Both fragmentation theory and polycentric governance can be seen as a form of regime complex. In both concepts, coordination between different governance arrangements within the whole architecture to integrate each program relating to common objectives is required. The government bodies need to better have coordination with non-state institutions in order to minimize conflict, particularly with regard to business and NGOs [11]. The interaction between actors within the regime can stimulate work on how to address conflict among institutions [12]. Good coordination with bigger regimes and a high level of institutionalisation through binding rules for partners are two of the main factors 
determining the success of an effective programme [18]. Once the good coordination turns to be a collaboration, it could serve the common good and positive impacts for shared prosperity [48].

\section{Conclusions}

This research applied the concept of fragmentation of regime complex and its policy output to the landscape of national biogas (as part of renewable energy) governance in Indonesia, focusing on the period from 2007 to 2017. The main results are as follows:

- The changes on the distribution of power and degree of cooperation within biogas governance architecture triggered periodical shifts of configuration within the regime, from administrative fragmentation in 2007-2009, to conflictive fragmentation in 2010-2012, to cooperative fragmentation in 2013-2016, and to reduced fragmentation (and centralisation) in 2017.

- The cooperation between state and non-state actors contributed to increasing the number of biodigester dissemination more than doubled in three years, from 16,730 in 2013, to 37,999 in 2016. This finding implies that higher degrees of cooperation and distribution of power within a governance architecture contribute to increasing the policy output of a (cooperative fragmentation) regime complex.

- The argument on cooperative fragmentation is further strengthened by the regime change in 2017 into the centralization model that reduces the distribution of power within the regime and contribute to influencing the decline of its policy output.

This study concludes that the fragmentation within renewable energy governance affects the dissemination of its technology and its related knowledge. These relations evolve over time and are based on the distribution of power and coordination among institutions within the regime. The existence of a diversity of energy initiatives works to accelerate innovation and to increase the speed of implementation. The speed of implementation can even be accelerated by having coordination and collaboration among the initiatives, such as in the cooperative fragmentation regime. This regime is found more favourable in tackling dissemination barriers in several aspects, such as shortening bureaucratic processes, speed up feedstock collection, improving social acceptance, increase the level of priority of the project, testing inclusive monitoring practices, and conducting technological maintenance. By contrast, conflictive fragmentation has shown to have mixed results. While conflictive ideas among actors triggers competition to create innovation, this competition (in the same geographical area) may also hamper opportunities to widening the technology dissemination.

This conclusion suggests that to trigger an increase in policy output, (national) renewable energy regimes need to have governance architectures that include a diversity of institutions with distributed power (resources) and effective cooperation among them. This architecture can be facilitated by a (group of) institutions who have high resources (authority, funding, and techno-scientific knowledge), to provide (in)formal provisions for supporting coordination among institutions across administrative levels, sectors, and types (state and non-state actors). This model can be tested for further research in countries in the Global South that promote decentralization and local governance.

Further research is required to identify the relationship between the institutions' coordination, power relations, and market functions, in multi-level governance settings. Furthermore, research should focus on key strategies that have the potential to catalyse a coordination setting within existing governance architectures and its relation to outcome evaluation.

Author Contributions: I.B. conceived the original idea, developed the conceptual framework, carried out the data collection, and performed the analysis, with support from M.S.; I.B. wrote the manuscript; M.S. helped supervise the writing process. All authors have read and agreed to the published version of the manuscript.

Funding: This work was supported by LPDP or Indonesian Endowment Fund for Education and Environmental Policy Group, Wageningen University and Research.

Conflicts of Interest: The authors declare no conflict of interest 


\section{Appendix A}

Table A1. List of interviews.

\begin{tabular}{|c|c|c|c|c|c|c|c|}
\hline \multicolumn{2}{|c|}{ Related Stakeholders > } & \multirow[t]{2}{*}{ National Government } & \multirow{2}{*}{$\begin{array}{c}\text { Local } \\
\text { Government }\end{array}$} & \multirow[t]{2}{*}{ Private Sectors } & \multirow[t]{2}{*}{ NGO } & \multirow[t]{2}{*}{ Civil Society } & \multirow[t]{2}{*}{ Academics } \\
\hline $\begin{array}{c}\text { Key } \\
\text { Institution }\end{array}$ & Programs & & & & & & \\
\hline $\begin{array}{l}\text { Hivos } \\
\text { (International } \\
\text { NGO) }\end{array}$ & $\begin{array}{l}\text { BIRU (Biogas for } \\
\text { household) }\end{array}$ & Ministry of Energy and Mineral Resources & $\begin{array}{l}\text { Agriculture } \\
\text { agency, Bandung } \\
\text { regency }\end{array}$ & $\begin{array}{c}\text { Construction } \\
\text { Partner } \\
\text { Organization; } \\
\text { Yayasan Kontak }\end{array}$ & $\begin{array}{l}\text { YRE (House of } \\
\text { energy } \\
\text { foundation) }\end{array}$ & $\begin{array}{c}\text { Loan partner } \\
\text { organization; } \\
\text { Local Farmers } \\
\text { cooperative } \\
\text { (KPSBU) }\end{array}$ & $\begin{array}{l}\text { su-re.co } \\
\text { (sustainability and } \\
\text { resilience-company) }\end{array}$ \\
\hline $\begin{array}{l}\text { Ministry of } \\
\text { energy and } \\
\text { mineral } \\
\text { resources } \\
\text { (MEMR) }\end{array}$ & $\begin{array}{l}\mathrm{RE} \text { (renewable } \\
\text { energy) programs }\end{array}$ & $\begin{array}{c}\text { MEMR } \\
\text { - } \quad \text { Directorate of bioenergy (DB) } \\
\text { - } \quad \text { Research center of RE (RCRE) }\end{array}$ & $\begin{array}{c}\text { Energy agency, } \\
\text { west java (EAWJ) }\end{array}$ & $\begin{array}{l}\text { SWEN (a } \\
\text { biodigester } \\
\text { company) }\end{array}$ & Hivos, YRE & & $\begin{array}{l}\text { Directorate of } \\
\text { research and } \\
\text { community } \\
\text { development, } \\
\text { University of } \\
\text { Indonesia, }\end{array}$ \\
\hline $\begin{array}{l}\text { Ministry of } \\
\text { Agriculture } \\
\text { (MA) }\end{array}$ & $\begin{array}{l}\text { BATAMAS (biogas } \\
\text { with community), } \\
\text { UPPO (organic } \\
\text { fertilizer unit) }\end{array}$ & \begin{tabular}{ll} 
& \multicolumn{1}{c}{ MA } \\
- & Directorate of livestock (DL) \\
- $\quad$ Directorate of agriculture infrastructure \\
Taskforce on climate change or TFCC in MA
\end{tabular} & $\begin{array}{l}\text { Agriculture } \\
\text { agency, Bandung } \\
\text { regency (AABR) }\end{array}$ & SWEN & & & $\begin{array}{l}\text { Bogor agriculture } \\
\text { institute }\end{array}$ \\
\hline \multirow[t]{2}{*}{$\begin{array}{l}\text { Ministry of } \\
\text { Environment } \\
\text { and Forestry } \\
\text { (MEF) }\end{array}$} & $\begin{array}{c}\text { Proklim, com-dev } \\
\text { in the conservation } \\
\text { area }\end{array}$ & $\begin{array}{ll}\text { - } & \text { Directorate of conservation (DC) } \\
\text { - } & \text { Directorate of climate change (DCC) }\end{array}$ & & SWEN & & & \\
\hline & $\begin{array}{l}\text { Coordination of } \\
\text { policy planning } \\
\text { and } \\
\text { implementation }\end{array}$ & $\begin{array}{ll}- & \text { Ministry of Development Planning } \\
\text { - } & \text { Ministry of coordinator of Maritimes (MCM) }\end{array}$ & & & & & \\
\hline
\end{tabular}




\section{Appendix B}

Table A2. List of reviewed documents.

\begin{tabular}{|c|c|c|}
\hline Key Institutions & Programmes/Topics & Project Reports, Policy Documents \\
\hline Hivos, YRE & BIRU & $\begin{array}{ll}\text { - } & \text { BIRU Annual report 2013-2017 } \\
\text { - } & \text { Final report, BIRU 2009-2013 } \\
\text { - } & \text { AGREEMENT between BIRU and MEMR, 2013, and its amendment in } 2014 \\
\text { - } & \text { BIRU, provincial report, } 2017 \\
\text { - } & \text { Sustainability of bioenergy for climate change, Transrisk and Greenwin, } 2017 \\
\text { - } & \text { Value creation bioslurry, } 2018 \\
\text { - } & \text { BIRU structural organization } \\
\text { - } & \text { Biodigester data per province, } 2016 \\
\text { - } & \text { Final report of impact assessment of BIRU, 2016 } \\
\text { - } & \text { The Indonesia domestic Biogas Programme, IIED } 2015 \\
\text { - } & \text { Work plan of BIRU, } 2015\end{array}$ \\
\hline $\begin{array}{l}\text { Ministry of energy } \\
\text { and mineral } \\
\text { resources (MEMR) }\end{array}$ & RE programs & $\begin{array}{ll}\text { - } & \text { Implementation of biogas production/projects, } 2018 \\
\text { - } & \text { Special allocation fund for household biogas projects, } 2018 \\
\text { - } & \text { Development of Indonesian biogas, } 2015 \\
\text { - } & \text { PEMANFAATAN BIOGAS DAK BIDANG ENERGI PERDESAAN TAHUN } 2014 \\
& \text { Work plan on biogas development, } 2015\end{array}$ \\
\hline $\begin{array}{c}\text { Ministry of } \\
\text { Agriculture (MA) }\end{array}$ & BATAMAS, UPPO & $\begin{array}{ll} & \text { UPPO report, 2008-2015 } \\
\text { - } & \text { Database of biogas, compost, and liquid fertilizer } \\
\text { - } & \text { Structural organization of the MA } \\
\end{array}$ \\
\hline \multirow[t]{3}{*}{$\begin{array}{l}\text { Ministry of } \\
\text { environment and } \\
\text { forestry (MEF) }\end{array}$} & $\begin{array}{l}\text { Proklim, com-dev in the } \\
\text { conservation area }\end{array}$ & $\begin{array}{l}\text { - } \\
\text { - } \\
\text { ADOP Emission Reduction of Biogas Utilization by Household Community In Bali, Indonesia, by Hiroshima University } \\
\text { - } \\
\text { TAMAN NASIONAL GUNUNG MERBABS } \\
\text { parks/conservation area }\end{array}$ \\
\hline & $\begin{array}{l}\text { Coordination of policy } \\
\text { planning and implementation }\end{array}$ & $\begin{array}{l}\text { - Indonesia as a maritime country, biogas as part of the renewable energy plan, by Ministry of coordinator of Maritimes } \\
\text { - } \quad \text { Bioslurry from biogas, UGM } 2015\end{array}$ \\
\hline & Policy and regulation & $\begin{array}{l}\text { - } \quad \text { Greenhouse gas emission reduction proposals and national climate policies of major economies, by ECOFYS and PBL } \\
\text { - } \quad \text { Presidential regulation no. 22/2017 on National energy planning } \\
\text { - } \quad \text { National energy policy, energy mix target (fossil fuel and renewables) } \\
\text { - } \quad \text { MRV FRAMEWORK FOR ENERGY COMPONENT OF RAN-GRK, Climate change mitigation, UNEP } 2016 \\
\text { - Climate action tracker, Indonesia }\end{array}$ \\
\hline
\end{tabular}




\section{References}

1. Austin, K.G.; Harris, N.L.; Wijaya, A.; Murdiyarso, D.; Harvey, T.; Stolle, F.; Kasibhatla, P.S. A review of land-based greenhouse gas flux estimates in Indonesia. Environ. Res. Lett. 2018, 13, 055003. [CrossRef]

2. Sunstein, C.R. The World vs. the United States and China-The Complex Climate Change Incentives of the Leading Greenhouse Gas Emitters. UCLA Law Rev. 2007, 55, 1675.

3. BPS. Persentase-Rumah-Tangga-Menurut-Provinsi-Dan-Bahan-Bakar-Utama-Untuk-Memasak-Tahun-2001-2007-2016; Badan Pusat Statistik: Jakarta, Indonesia, 2016.

4. Jeuland, M.A.; Pattanayak, S.K. Benefits and costs of improved cookstoves: Assessing the implications of variability in health, forest and climate impacts. PLoS ONE 2012, 7, e30338. [CrossRef] [PubMed]

5. Griffiths, H. Biogas: Global trends and exciting opportunities for South Africa. 2013. Available online: https://www.ee.co.za/wp-content/uploads/legacy/Energize_2013/08_ST_02_sde_biogas.pdf (accessed on 8 February 2020).

6. Gu, L.; Zhang, Y.X.; Wang, J.Z.; Chen, G.; Battye, H. Where is the future of China's biogas? Review, forecast, and policy implications. Pet. Sci. 2016, 13, 604-624. [CrossRef]

7. Yisheng, Z.; Minying, Y.; Zhenn, S. Rural energy policy in China. In Presentation in Stanford/TERI Workshop on Rural Energy Transitions, New Delhi; Institute of Quantitative and Technical Economics, Chinese Academy of Social Sciences: Beijing, China, 2002; pp. 5-7.

8. Bond, T.; Templeton, M.R. History and future of domestic biogas plants in the developing world. Energy Sustain. Dev. 2011, 15, 347-354. [CrossRef]

9. Mahapatra, S.; Chanakya, H.N.; Dasappa, S. Evaluation of various energy devices for domestic lighting in India: Technology, economics and $\mathrm{CO}_{2}$ emissions. Energy Sustain. Dev. 2009, 13, 271-279. [CrossRef]

10. Rupf, G.V.; Bahri, P.A.; de Boer, K.; McHenry, M.P. Barriers and opportunities of biogas dissemination in Sub-Saharan Africa and lessons learned from Rwanda, Tanzania, China, India, and Nepal. Renew. Sustain. Energy Rev. 2015, 52, 468-476. [CrossRef]

11. Biermann, F.; Pattberg, P.; van Asselt, H.; Zelli, F. The fragmentation of global governance architectures: A framework for analysis. Glob. Environ. Politics 2009, 9, 14-40. [CrossRef]

12. Zelli, F.; van Asselt, H. Introduction: The institutional fragmentation of global environmental governance: Causes, consequences, and responses. Glob. Environ. Politics 2013, 13, 1-13. [CrossRef]

13. de Santoa, E.M.; Asgeirsdottir, A.; Barros-Platiau, A.; Biermann, F.; Dryzek, J.; Gonçalves, L.R.; Kim, R.E.; Mendenhall, E.; Mitchell, R.; Nyman, E.; et al. Protecting biodiversity in areas beyond national jurisdiction: An earth system governance perspective. Earth Syst. Gov. 2019, 2, 100029. [CrossRef]

14. Transrisk. Report on Social Discourse Analyses and Social Network Analyses; Horizon 2020: Stockholm, Sweden, 2017.

15. Fernández-Blanco, C.R.; Burns, S.L.; Giessen, L. Mapping the fragmentation of the international forest regime complex: Institutional elements, conflicts and synergies. Int. Environ. Agreem. Politics. Law Econ. 2019, 19, 187-205. [CrossRef]

16. Gupta, A.; Pistorius, T.; Vijge, M.J. Managing fragmentation in global environmental governance: The REDD+ Partnership as bridge organization. Int. Environ. Agreem. Politics Law Econ. 2016, 16, 355-374. [CrossRef]

17. Zelli, F. The fragmentation of the global climate governance architecture. Wiley Interdiscip. Rev. Clim. Chang. 2011, 2, 255-270. [CrossRef]

18. Dzebo, A. Effective governance of transnational adaptation initiatives. Int. Environ. Agreem. Politics. Law Econ. 2019, 19, 447-466. [CrossRef]

19. Geddes, A. The governance of migration in Europe: Towards fragmentation? In Handbook of Migration and Globalisation; Edward Elgar Publishing: Troutham, UK, 2018.

20. Charnoz, O.; Forster, P. The global health impact of local power relations: Fragmented governance, big business and organisational bias in Indonesian animal health policies. Glob. Gov. Work. Pap. 2011, 2, 2011.

21. Jessop, B. Territory, politics, governance and multispatial metagovernance. Territ. Politics Gov. 2016, 4, 8-32. [CrossRef]

22. Derkx, B.; Glasbergen, P. Elaborating global private meta-governance: An inventory in the realm of voluntary sustainability standards. Glob. Environ. Chang. 2014, 27, 41-50. [CrossRef] 
23. Biermann, F.; Kanie, N.; Kim, R.E. Global governance by goal-setting: The novel approach of the UN Sustainable Development Goals. Curr. Opin. Environ. Sustain. 2017, 26, 26-31. [CrossRef]

24. Lindstad, B.H. Changes in Norwegian forest policies: What are the effects of the international forest regime complex? Scand. J. For. Res. 2015, 30, 246-254. [CrossRef]

25. Clift, B. Tangled Governance: International Regime Complexity, the Troika, and the Euro Crisis; Henning, C.R., Ed.; Oxford University Press: Oxford, UK, 2017; p. 312.

26. Shivakoti, R.; Howlett, M.; Fernandez, V.; Nair, S. Governing international regime complexes through multi-level governance mechanisms: Lessons from water, forestry and migration policy. Int. J. Water Resour. Dev. 2019, 1-18. [CrossRef]

27. Cullet, P. Differential treatment in international law: Towards a new paradigm of inter-state relations. Eur. J. Int. Law 1999, 10, 549-582. [CrossRef]

28. Smits, M. The New (Fragmented) Geography of Carbon Market Mechanisms: Governance Challenges from Thailand and Vietnam. Glob. Environ. Politics 2017, 17, 69-90. [CrossRef]

29. Pahl-Wostl, C.; Knieper, C. The capacity of water governance to deal with the climate change adaptation challenge: Using fuzzy set Qualitative Comparative Analysis to distinguish between polycentric, fragmented and centralized regimes. Glob. Environ. Chang. 2014, 29, 139-154. [CrossRef]

30. Knill, C.; Lenschow, A. Coping with Europe: The impact of British and German administrations on the implementation of EU environmental policy. J. Eur. Public Policy 1998, 5, 595-614. [CrossRef]

31. Keohane, R.O.; Victor, D.G. The regime complex for climate change. Perspect. Politics 2011, 9, 7-23. [CrossRef]

32. Underdal, A.; Young, O.R. Regime Consequences: Methodological Challenges and Research Strategies; Springer: Berlin/Heidelberg, Germany, 2004.

33. Crabb, A.; Leroy, P.; Leroy, P. The Handbook of Environmental Policy Evaluation; Routledge: Abingdon, UK, 2012.

34. Kementan. Database Fasilitasi Pengolahan Biogas, Kompos Dan Pupuk Cair; Kementrian Pertanian: Jakarta, Indonesia, 2018.

35. Kementrian ESDM. Realisasi Program Biogas; Directorate of Bioenergy: Jakarta, Indonesia, 2018.

36. MEMR. Realisasi Program Biogas; Ministry of Energy and Mineral Resources Indonesia: Jakarta, Indonesia, 2018.

37. Galaz, V.; Crona, B.; Österblom, H.; Olsson, P.; Folke, C. Polycentric systems and interacting planetary boundaries-Emerging governance of climate change-ocean acidification-marine biodiversity. Ecol. Econ. 2012, 81, 21-32. [CrossRef]

38. Widerberg, O.; Pattberg, P. International cooperative initiatives in global climate governance: Raising the ambition level or delegitimizing the UNFCCC? Glob. Policy 2015, 6, 45-56. [CrossRef]

39. Krysanova, V.; Dickens, C.; Timmerman, J.; Varela-Ortega, C.; Schlüter, M.; Roest, K.; Huntjens, P.; Jaspers, F.; Buiteveld, H.; Moreno, E.; et al. Cross-comparison of climate change adaptation strategies across large river basins in Europe, Africa and Asia. Water Resour. Manag. 2010, 24, 4121-4160. [CrossRef]

40. Lieberman, E.S. The perils of polycentric governance of infectious disease in South Africa. Soc. Sci. Med. 2011, 73, 676-684. [CrossRef]

41. Biesbroek, G.R.; Lesnikowski, A. The Neglected Dimension of Polycentric Climate Governance? Gov. Clim. Chang. 2018, 303-319. [CrossRef]

42. Goldthau, A. Rethinking the governance of energy infrastructure: Scale, decentralization and polycentrism. Energy Res. Soc. Sci. 2014, 1, 134-140. [CrossRef]

43. Homsy, G.C.; Warner, M.E. Cities and sustainability: Polycentric action and multilevel governance. Urban Aff. Rev. 2015, 51, 46-73. [CrossRef]

44. Marshall, G.R. Nesting, subsidiarity, and community-based environmental governance beyond the local level. Int. J. Commons 2008, 2, 75-97. [CrossRef]

45. Ostrom, E. Beyond markets and states: Polycentric governance of complex economic systems. Am. Econ. Rev. 2010, 100, 641-672. [CrossRef]

46. Ostrom, E. Vulnerability and polycentric governance systems. IHDP Update 2001, 3, 1-4. 
47. Pahl-Wostl, C. Governance of the water-energy-food security nexus: A multi-level coordination challenge. Environ. Sci. Policy 2019, 92, 356-367. [CrossRef]

48. Zhang, Y. Governing the water commons in China: From historical oriental despotism to contemporary fragmented hydraulic state. Int. J. Water Resour. Dev. 2019, 35, 1029-1047. [CrossRef]

(C) 2020 by the authors. Licensee MDPI, Basel, Switzerland. This article is an open access article distributed under the terms and conditions of the Creative Commons Attribution (CC BY) license (http://creativecommons.org/licenses/by/4.0/). 